\title{
An assessment of selected traditional leaders from the Sarkin Musulmi Abubakar Atiku family and their domains in Africa
}

\author{
Yusuf Sarkingobir*1 | Fatima G. Abubakar ${ }^{2}$ | Tambari Abbas Bashar ${ }^{3}$ \\ 1. Department of Biology, Shehu Shagari College of Education Sokoto, Nigeria. \\ 2. Department of Islamic Studies, Shehu Shagari College of Education Sokoto, Nigeria. \\ 3. Department of Islamic Studies, Usmanu Danfodiyo University Sokoto, Nigeria. \\ *Corresponding Author Email: superoxidedismutase594@gmail.com
}

\begin{abstract}
This paper briefly discussed some of the Atikawa who had been on their rightful thrones and their domains. This was achieved via literature review and interviews with key informants. This paper explained that Caliph Abubakar Atiku had contributed immensely to the development and progress of the Sokoto Caliphate during the jihad of Shehu Usman Danfodiyo. It was found that Caliph Abdurrahman Atiku reigned 18911902, the last direct grandchild of Shehu to be on the throne. Attahuiru (the son of Ahmad) reigned in 1902-1903 and was the one who fought the final battle with the British. His descendants are presently holding a Sultanate throne in Maiyurno, Sudan. Some of his disciples spread to Makkah, Mali, and many other parts of the world. His time allowed the Shehu's jihad to reach international space. Maiturare (son of Amadu) became sultan in 1915-1924 and was the most successful after the invasion of the Sokoto Caliphate by the British. He was preceded by his son, Muhammadu Tambari, who left the throne in 1931. Apart from Sultanate, the descendants of Atiku had built many towns and villages and managed them to greatness.
\end{abstract}

Article History

Received:

April 18, 2021

Revised:

August 28, 2021

Accepted:

September 3, 2021

Published:

October 3, 2021

Keywords: Atikawa, Sokoto Caliphate, Sultan, Sultanate, Caliph, Abubakar Atiku, Gwadabawa, throne, reign, hegemony.

How to Cite: Sarkingobir, Y., Abubakar, A. G., Bashar, T. A. (2021). An assessment of selected traditional leaders from the Sarkin Musulmi Abubakar Atiku family and their domains in Africa. Liberal Arts and Social Sciences International Journal (LASSIJ), 5(2), 109-123. https://doi.org/10.47264/idea.lassij/5.2.8

Publisher's Note: IDEA PUBLISHERS (IDEA Journals Group) stands neutral with regard to the jurisdictional claims in the published maps and the institutional affiliations.

Copyright: (C 2021 The Author(s), published by IDEA PUBLISHERS (IDEA Journals Group).

Licensing: This is an Open Access article published under the Creative Commons AttributionNonCommercial 4.0 International License (http://creativecommons.org/licenses/by-nc/4.0/) 


\section{Introduction}

In Africa, the $19^{\text {th }}$ century was opened with the 1804 Sokoto Jihad led by Usman Danfodiyo, which challenged the status quo in Hausaland and beyond on fundamental issues of governance, religion, and social justice. Shehu Usman Danfodiyo masterminded that movement. Inturn, Shehu led the formation of the biggest federation in the history of West, Central, and other parts of Africa (Abba et al., 2017; Sheriff \& Altine, 2018). Sokoto Caliphate was initially a formation led by a crowd of young intellectuals and scholars anchored by Usman Danfodiyo. There is one important personality called Abubakar Atiku was the closest to Shehu Danfodiyo and had always been near Shehu in thin and thick. Abubakar Atiku, like his brother Muhammadu Bello, had contributed his all to the Sokoto Caliphate's accomplishment in nascent and development times (Abba et al., 2017). He sired a ruling house called Atikawa, who had been relevant and immensely influential in Sokoto Caliphate since its inception. Despite, their contributions written literature about them are scanty (Johsnton, 1967; Johnston, 2010; Sarkingobir, 2020a; Sarkingobir, 2020b; Sarkingobir \& Sharu, 2021).

Abubakar Atiku was the $4^{\text {th }}$ son of Shehu Danfodiyo of Nineteen Century West African. He picked up many responsibilities given to him by Sultan Muhammadu Bello to safeguard Sokoto Caliphate. He sired many scions who had also contributed to the Caliphate of Sokoto. His descendants are popularly known as Atikawa. He later succeeded Caliph Muhammad Bello; Atiku ensured justice on the land and prohibited wrongdoings and cleared innovations. Likewise, his scions and descendants contributed to the consolidation of Sokoto. His son Ahmadu Atiku succeeded as Caliph in 1859-1866; Shehu postulated his period, characterized by spreading peace and overcoming forces attacking the Sokoto Caliphate. Thus, the objective of this paper is to deal with some Atiku's scions and their hegemony domains in brief. A review of related literature and oral interviews were undertaken to achieve the said objective.

\section{Atiku's scions and their domains}

\subsection{Sultan of Sokoto}

The scions of Sarkin Musulmi Abubakar Atiku 1 had been among the top contenders and heirs to Sultanate stool since after the death of Sarkin Musulmi Muhammadu Bello to date. Some of them had succeeded in becoming Sarkin Musulmi (Ummaru, 1999; Shareef, 2005; Sarkingobir, 2020a; Sarkingobir, 2020b; Sarkingobir \& Sharu, 2021). Some people from the Atiku dynasty who had successfully occupied the Sultanate throne are shown below table-1.

Table-1: Atiku dynasty who had occupied the Sarkin Musulmi stool

\begin{tabular}{|l|l|}
\hline Name of Sarkin Musulmi & Time/years on the throne \\
\hline Abubakar Atiku & $1837-1842$ \\
\hline Ahmadu Atiku (Zaruku) & $1859-1866$ \\
\hline Abdurrahman Atiku & $1891-1902$ \\
\hline Attahiru Ahmad 1 & $1902-1903$ \\
\hline Muhammadu Maiturare Gwadabawa & $1915-1924$ \\
\hline Muhammadu Tambari & $1924-1931$ \\
\hline
\end{tabular}




\subsection{Sarkin Musulmi Abdurrahman}

Traditions revealed that Abdurrahman was born in 1926. Abdurrahman was the one who established Jabo town. He also found Fajaldu, Dandinmahe among others. He became Sarkin Musulmi during a time when the Sokoto Caliphate was about to be invaded by the British. Abdurrahman was raised as a very brave and upright macho. The incident which led to the selection of Abdurrahman ascaliph was the death of Sarkin Musulmi Ummaru. There was a time when Sarkin Musulmi Ummaru (1881-1891) travelled to Zamfara (Kaura Namoda). He died on that fateful trip. When Abdurrahman was intimated that Sarkin Musulmi Ummaru was going to Zamfara with few aides and council members, he feared for the life of Sarkin Musulmi; in addition to that, he covertly followed the Sarkin Musulmi to ensure that no harm befalls on the Sarkin Musulmi, but Almighty has already written that the Sarkin Musulmi will die on that trip, no one can avail him. Thus, by the time Sarki Ummaru passed away, only Abdurrahman was around among the princes; henceforth, Waziri Bukhari, after deliberations, successfully appointed Abdurrahman as Sarkin Musulmi to rule in the next 1891-1902.

Traditionally, Sarki stool rotates in between the two houses of Bello and Atiku. That was one of the portents which favoured Abdurrahman to be selected as Sarkin Musulmi, because the immediate Sarkin Musulmi Ummaru was from the house of Bello and the Atiku house had been away from the Sarkin Musulmi throne since from the time of Amadu Atiku. Another factor in favour of Abdurrahman was the use of seniority, been Abdurrahman as the direct grandchild of Shehu Usman Danfodiyo. He was then one of the seniors therein, and seniority is treated with the utmost respect (Ummaru, 1999; Shareef, 2005; Sarkingobir, 2020a; Sarkingobir, 2020b).

\subsection{Sarkin Zamfara}

Sarkin Zamfara's title was initially given to Abubakar Atiku's brother to Sarkin Musulmi Muhammadu Bello to monitor Zamfara Region. Atiku also held other posts before he became Sarkin Musulmi. Later, the Sarauta of Sarkin Zamfara was allotted to Amadu Atiku, the son of Sarkin Musulmi Atiku, who later became Sarkin Musulmi. Amadu was popularly known as Amadu Zaruku or Amadu Maichimmola. The Sarkin Zamfara, when given to Amadu Atiku, was an authority to act as supervisor of Zamfara Sarakuna (because of the characteristic uprising that was their nature in those years). Parable, he was asked to monitor the unhappy conduct of Sarkin Mafara Agwaragi at that time. When he became Sarkin Musulmi, the title was given to his brother Muhammadu, son of Atiku, then Amadu Rufa'i son of Atiku, and other successive occupants who came come later. Sarkin Zamfara's title was reserved for Atikawa to contribute their own quota to developing and manipulating the Sokoto Caliphate. When Sarkin Musulmi left Sokoto for ribat or other purposes, Sarkin Zamfara was vested with the responsibility to act in his capacity in Sokoto.

Forsooth, Sarkin Zamfara was the governor of Sokoto City with or without the presence of Sarkin Musulmi in town. Moreover, Sarkin Zamfara was saddled with the responsibility of hiring and firing of northern hakimai of Sokoto City such as Maiunguwar Sabon Birnin Sokoto, Marina, Tsamiya, Ubandoman Kofar Atiku, Mafaran Konni, Zoramawa, and Danchadi. During colonialism, he was vested with the responsibility of internuncial between the Sarkin Musulmi and Turawa and afterward during the military regimes. Later, Sarkin Zamfara was permanently settled at Danchadi town, few kilometres away from Sokoto Metropolis. Sources showed that it was Sarkin Zamfara Abdulkadir Mujeli that was initially instructed to settle at Danchadi 
permanently. Still, Sarkin Zamfara is very important in the discharge of the Sokoto Sultanate and preserved to the Atikawa house (Ummaru, 1999; Sarkingobir, 2020a; Sarkingobir, 2020b;). To ascertain the people who had been on Sarkin Zamfara's throne, three documents were obtained (1 from Dan Masanin Gwadabawa, two from village head of Takatuku, Dangaladiman 2020), but there were inconsistencies in the number of years the Sarkin Zamfara reigned. Thus, we chose to adopt one version of the documents, as shown below table-2.

Table-2: The Sarakunan Zamfara in Sokoto Caliphate

\begin{tabular}{|c|c|c|}
\hline Sarkin Zamfara & $\begin{array}{l}\text { Duration of } \\
\text { reign }\end{array}$ & Remarks \\
\hline \multicolumn{3}{|c|}{$\begin{array}{l}\text { Amadu Atiku } \text { (who } \\
\text { once became Sarkin } \\
\text { Musulmi) }\end{array}$} \\
\hline \multicolumn{3}{|l|}{$\begin{array}{l}\text { Muhammadu } \mathrm{Na} \\
\text { Bakura son of Atiku } 1\end{array}$} \\
\hline \multicolumn{3}{|l|}{$\begin{array}{l}\text { Amadu Rufa'i son of } \\
\text { Atiku 1 }\end{array}$} \\
\hline \multicolumn{3}{|l|}{ Hassan, son of Atiku } \\
\hline \multicolumn{3}{|l|}{ Dalhatu, son of Atiku 1} \\
\hline $\begin{array}{l}\text { Abubakar Gugara son } \\
\text { of Amadu Atiku } 1\end{array}$ & $1873-1903$ & \\
\hline $\begin{array}{l}\text { Malam Ibrahim son of } \\
\text { Amadu }\end{array}$ & 1903-1909 & \\
\hline Abdullahin Dan Amadu & 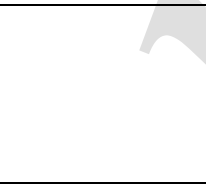 & $\begin{array}{l}\text { From the first Sarkin Zamfara to this one, the owner of the } \\
\text { title is responsible for the supervision of Zamfara Region } \\
\text { (nowadays Zamafara state) and mayor or Governor of the } \\
\text { Sokoto City }\end{array}$ \\
\hline Abdullkadir Mujeli & $1909-1942$ & $\begin{array}{l}\text { He was the one who was asked to settle at Danchadi } \\
\text { permanently }\end{array}$ \\
\hline $\begin{array}{l}\text { Aliyu Dan Abdulkadir } \\
\text { Mujeli }\end{array}$ & $1942-1962$ & . \\
\hline $\begin{array}{l}\text { Muhammadu Kwasau } \\
\text { son of Abdulkadir } \\
\text { Mujeli }\end{array}$ & $1963-1974$ & $\begin{array}{l}\text { Transferred to Tangaza and succeeded Bunu Muhammadu } \\
\text { Zayyanu, who was then transferred to Gwadabawa as } \\
\text { Sarkingobir Gwadabawa }\end{array}$ \\
\hline $\begin{array}{l}\text { Yusufu son } \\
\text { Abdulkadir Mujeli }\end{array}$ & 1974-1980 & \\
\hline $\begin{array}{lr}\text { Muhammadu } & \text { Dan } \\
\text { Gwadabawa son of } \\
\text { Kwasau }\end{array}$ & 1981 & \\
\hline Garba Yusuf Danchadi & & Present Sarkin Zamfara Danchadi \\
\hline
\end{tabular}

\subsubsection{The owner of Gwadabawa: Marafa/Sarkingobir Gwadabawa}

The Gwadabawa metropolitan district was created as a ribat to solve the main issues facing the nascent Sokoto Caliphate. The matters of settlement scarcity, insecurity, food insecurity, and others were overhauled in the northern part of Sokoto Caliphate by the creator of the Gwadabawa district Muhammadu Maiturare Marafa (who later became Sarkin Musulmi and ruled in 1914-1925). The old Gwadabawa District consisted of vast regions encircling the present-day Gudu, Tangaza, Gwadabawa, Illela, and Gada local governments (Sarkingobir, 2020a; Sarkingobir, 2020b). All the new/present districts in these local governments belonged 
to Gwadabawa and Muhammadu Maiturare or his descendants. If the rightful traditions are followed, no one is eligible to be turbaned as a district head in the old or new Gwadabawa regions except the Maiturare house. This was the rightful tradition been trailed until politics led to some aberrations.

In-line with the practices of the Caliphate or Sultanate, lands are owned by people who give life to them. Hadith and Maliki's school of law echoed that "Whosoever gives life to a land belonging to no one, it now belongs to him. "Whereas Maiturare created Gwadabawa Metropolitan district from nothing, thus he is the sole owner of this region, and the ownership is heretical. When Maiturare created Gwadabawa, his title was Marafa Gwadabawa, and he continued to bore the title till he became Sarkin Musulmi. Therein, the title of Sarautar Gwadabawa was changed to Sarkingobir, which is still being retained as the bonafide title and the head of the Atikawa dynasty. The allocation of Sarkingobir's title to Gwadabawa was borne out of the sheer power of Maiturare and the dealings of Gobirawa and their Fulani friends. Maiturare was popularly hymned as "Maiturare Gogarma Dan Amadu. Alkalinka Allah" in the Hausa Language, which means" Maiturare Giant (machonic), the son of Ahmadu. Your judge is only God. "Maiturare has been feared during his time because of his spectacular excess braveness, virility, and macho (Sokoto State History Bureau, 1979; Tibenderana,1997; Ummaru, 1999; Jabo, 2008; Ayama, 2018).

Table-3: list of Sarakunan Gwadabawa, Sokoto, Nigeria

\begin{tabular}{|l|c|c|}
\hline Name of Sarki & Date & Duration \\
\hline $\begin{array}{l}\text { Sarkin Musulmi Muahmmadu Maiturare, he was on the throne as } \\
\text { Marafan Gwadabawa, later the title was changed to Sarkingobir }\end{array}$ & $1880-1915$ & 35 \\
\hline $\begin{array}{l}\text { Sarkin Musulmi Muhammadu Tambari son of Maiturare, was the first } \\
\text { to be called as Sarkingobir }\end{array}$ & $1915-1924$ & 9 \\
\hline Sarkingobir Ahamadu Zaruku, the son of Sultan Maiturare & $1924-1929$ & 5 \\
\hline Sarkingobir Adiya, the son of Sultan Tambari & $1929-1931$ & 2 \\
\hline $\begin{array}{l}\text { Sarkingobir Abdurrahman Jatau, the 4th son of Sarkin Musulmi } \\
\text { Maiturare }\end{array}$ & $1931-1968$ & 37 \\
\hline Sarkingobir Muhammad Bello, son of Abdujatau & $1968-1974$ & 6 \\
\hline Sarkingobir Zayyanu (Zayyana), the Son of AbduJatau & $1974-2014$ & 39 \\
\hline Sarkingobir Muhammadu Lawal, the son of Muhammadu Zayyanu & $2014-$ date & \\
\hline
\end{tabular}

Source: Adapted from Jabo, 2008

\subsubsection{Establishement of Kadassaka/ Gada district from Gwadabawa}

Kadassaka was in the domain of Gwadabawa district, created by Maiturare. It was a place bordering the Niger Republic blessed with land and vegetation. Maiturare boosted the region by ensuring the security of the dwellers and provision of vast land for agriculture. When Tambari (son of Maiturare) succeeded as Sultan, he made Kadassaka new District carved from Gwadabawa. Tambari appointed his son Hassan as Bunun Kadassaka in 1925. Kadassaka seized to exist as district in 1932 when it was re-joined to Gwadabawa district. In 1939 Kadassaka was further removed from Gwadabawa and named as Gada District. The headquarter was relocated to Gada Town. Gada Town derived its name from one Hunter called 
Gada. Initially, Gada had an extension from Gaidau (of Illela) to Gambuwal, about 80 kilometres, and from Gidan KWANNI to Lamba, about 100km. It had a time when it possessed ten hakimai (village heads) such as Gada, Kyadawa, Kadassaka, Kwarma, Kadadi, Dukamaje, Kaffe, Kaddi, Gilbadi, Tsitse, and Ilah. The famous tribes in Gada consisted of Gobirawa, Adarawa, Hausawa, Kwannawa, and Fulani (Ministry of Information, Cultural, and Internal Affairs, Sokoto State, 1979; Ummaru, 1999).

Table-4: Sarakunan Gada/Kadassaka District of old Gwadabawa, Sokoto Caliphate

\begin{tabular}{|c|c|c|}
\hline $\begin{array}{l}\text { Name of Basarake and } \\
\text { his title }\end{array}$ & $\begin{array}{l}\text { Duration of } \\
\text { reign }\end{array}$ & Remarks \\
\hline Bunu Hassan & 1925 & Son of Tambari (son of Sarkin Musulmi Maiturare) \\
\hline $\begin{array}{l}\text { Bunu } \quad \text { Muhammadu } \\
\text { Adiya }\end{array}$ & $1926-1931$ & Son of Tambari (son of Sarkin Musulmi Maiturare) \\
\hline Bunu Yusuf & 1931 & Son of Maiturare \\
\hline Sarkin Rafi Alu & 1932 & $\begin{array}{l}\text { Son of Maiturare. After him, the district was returned to } \\
\text { Gwadabawa }\end{array}$ \\
\hline Marafa Ibrahim Dasuki & 1939 & $\begin{array}{l}\text { Grandchild of Maiturare. The Kadassaka was again } \\
\text { removed from Gwadabawa and named as Gada district. }\end{array}$ \\
\hline \multicolumn{3}{|l|}{ Sarkin Zamfara Aliyu } \\
\hline $\begin{array}{l}\text { Marafa Muhammadu } \\
\text { Bello Abdurrahman }\end{array}$ & $1974-2004$ & $\begin{array}{l}\text { Son of Sarkingobir Gwadabawa Abdurrahman son of } \\
\text { Maiturare Gwadabawa }\end{array}$ \\
\hline $\begin{array}{l}\text { Marafa Kabiru Aliyu } \\
\text { Kyari }\end{array}$ & 2005 & $\begin{array}{l}\text { Son of Marafa Muhammadu Bello, son of Maiturare } \\
\text { Gwadabawa }\end{array}$ \\
\hline
\end{tabular}

\subsubsection{Removal of Tangaza district from Gwadabawa district in the time of Sultan Muhammadu Maiturare}

After Muhammadu Maiturare had established Gwadabawa, he descended westward (Yamma) and moved into a vast bush blessed with agricultural land. Therein, Fulani and other tribes migrated to this region to utilize this blessed land of farming practices. During that time, the land was characterized bya preponderance number of wild animals. Muhammadu Maiturare established a town called Tangaza in this vast region, and he appointed Ardo Bizu to lead the dwellers of Tangaza. Ardo Bizu was the first person to be appointed as supervisory leader in the whole Tangaza region of Gwadabawa Metropolitan District because most of its inhabitants are Fulani people attracted by the vast land for farming and rearing of livestock.

Progressively, Tangaza became enriched with settlers until it reached Dogon Dutsi (border with the Niger Republic). It had a border with the Binji region and Kebbi land. When Maiturare became Sarkin Musulmi, he appointed his son Amadu (who later ascended as Sarkingobir Gwadabawa during the time of Tambari as Sarkin Musulmi) from then the leadership was collected from Ardo Bizu. Tangaza district became developed into wards (village heads) such as Tangaza, Gidanadi, Magwanho, Balle, Kurdula, Sakkwai, Ruwa Wuri, Kwaccehuru, Salewa, Bachaka, KarfenSarki. Tangaza is famous for its historical legend to the establishment and development of the Sokoto Caliphate. After Tangaza, Muhammadu Maiturare established some villages such as Gandeand Wahittu, which presently are no longer parts of his domain (Tibenderana, 1997; Ummaru, 1999; Jabo, 2008; Ayama, 2018; Sarkingobir, 2021a; Sarkingobir, 2021d). 
Table-5: Sarakunan Tangaza District of old Gwadabawa District

\begin{tabular}{|l|l|l|}
\hline Bunun Tangaza & $\begin{array}{l}\text { Duration of } \\
\text { reign }\end{array}$ & Remarks \\
\hline Marafa Ahmadu Zaruku & $1918-1927$ & Son of Maiturare Gwadabawa \\
\hline Marafa Ali & $1927-1932$ & Son of Maiturare \\
\hline Marafa Hassan & $1932-1934$ & Son of Tambari \\
\hline Marafa Isah & $1934-1946$ & Son of Maiturare \\
\hline Bunu Shehu & $1946-1961$ & Son of Maiturare \\
\hline Bunu Hamza & $1961-1972$ & Son of Maiturare \\
\hline $\begin{array}{l}\text { Bunu } \text { Zayyana } \\
\text { Sarkin Zamfara } \\
\text { Muhammadu Kwasau }\end{array}$ & $1972-1974$ & Son of Sarkingobir Abdurrahman, son of Maiturare \\
\hline Marafa Jabbo Wandara & $1974-1991$ & \\
\hline Marafa Abubakar Marafa & $2013-2020$ & Brother to Marafa Jabbo Wandara \\
\hline
\end{tabular}

In 1997 under the leadership of Sarkin Musulmi, Muhammadu Macchido Gudu was carved out of Tangaza and returned as Gudu district, which was allocated to Muhammadu Bello Ayama, the son of Bunu Shehu, son of Sarkin Musulmi Muhammadu Maiturare. This allocation was initially handled by the Head of Atikawa of that time, the Sarkingobir Gwadabawa Muhammadu Zayyanu, who later directed it to the Muhammadu Bello Ayama (Ummaru, 1999; Jabo, 2008; Ayama, 2018).

\subsubsection{Establishment of Illela district of Gwadabawa}

Initially, the Illela land is part of the whole region engulfed by Gwadabawa district, which Muhammadu Maiturare Marafa formed before becoming Sarkin Musulmi. Later, when Abdurrahman became Sarkingobir of Gwadabawa, he created the Illelaward in 1935. Before the pioneer creation of Illela ward, the place was naught but a vast fertile land, water, and mud. That is why it once served as a hub for livestock reapers and served as a demarcation between the Niger Republic and Sokoto. The quest for maintaining security, the sought to create farmlands, the quest for taking the government to the grassroots, and other reasons spurred Sarkingobir Abdurrahman to create this ward. Sarkingobir removed some villages from other wards such as Garu, Kalmalo. Parable, Sonane, Amarawa, and Tudun Gudale were added to Illela ward. This ward was vivified and reinvigorated to later became the next hub of commerce in Sokoto State and very important in the whole country and crucial in international trade (Ummaru, 1999; Jabo, 2008; Ayama, 2018).

People across the states like Lagos, Kano, Kebbi, Zamfara, Katsina, Niger, and the Niger Republic always trooped to Illela to perform their businesses in Illela. During the time of Yakubu Muazu as Governor of Sokoto Illela Market was officially inaugurated as International Market. This had also happened during the time of Governor Wamakko of Sokoto State. The person who was initially turbaned as Hakimin Illela by Sarkingobir Gwadabawa Abdurrahman was the old Ubandawakin Matankarin Kalmalo because he had served Abdurrahman diligently and loyally when he settled at Illela. In a move to requite Ubandawaki, that was what Abdurrahman did to him by elevating him from aide to Hakimi (village head). Onwards, the 
cordial relationship has continued between the descendants of Sarkingobir Abdurrahman and the Ubandawaki scions. During the turban, the village head title SabongarinIlela, until later, the descendants sought to change the title to Ubandawaki. Thus, as of today, some of the descendants are bearing Sabongari and Ubandawaki titles, respectively (Ummaru, 1999; Jabo,2008; Ayama, 2018). Since the creation of the Illela ward, the people who occupied the village-headship title were listed in the below table- 6 .

Table-6: Village heads of Illela since its creation by Sarkingobir Abdurrahman Gwadabawa, son of Maiturare

\begin{tabular}{|l|c|}
\hline Name of village heads & Duration \\
\hline Ubandawaki Amadun Matankari & 21 \\
\hline Ubandawaki Muhammadu Awakin Karo & 21 \\
\hline Ubandawaki Muhammadu Almustapha & 9 \\
\hline Ubandawaki Idi & 13 \\
\hline Ubandawaki Usuman & 8 \\
\hline Ubandawaki Bako & 4 \\
\hline Ubandawaki Isa (Gado) & 37 \\
\hline Sabongari Muhammadu Dan Aljimma & 3 \\
\hline Sabongarin Abdu Dan Baro & 29 \\
\hline Sabongari Isa Ummar & \\
\hline
\end{tabular}

In 1997, the Illela district was created from Gwadabawa district and was handed over to Muhammadu Tukur Abdulrahman (grandson of Sarkin Musulmi Muhammadu Maiturare). After his death, the leadership stool was given to his son Muhammadu Buhari Tukur in 2020. From the onset, the Illela district consisted of Araba, Kalmalo, Sabongarin Darna, Gidan Hamma, Darnar Tsolawo, Damba, Garu, Lakoda, Gatti, Bakin Dutsi, Lafani, Tudun Aya, Gidan Ciwake, Sonani, Jagai, Danboka, Karingo, Masawa, Gidan Kira, Inwala, Jagai, Gidan Tudu, Illela. They were initially established by Muhammadu Maiturare Marafa (Ummaru, 1999; Ayama, 2018).

\subsubsection{Wauru district of old Gwadabawadistrict}

Wauru town was initially in the whole Gwadabawa District, which was allocated to Gada/ Kadassaka district after removing Gada/Kadassaka from Gwadabawa district. Thus, it served as ward following Gada/Kadassaka in the olden days. Later, in 1997 Wauru district was carved out from Gada and Muhammadu Balarabe Adiya was turbaned as Bunun Wauru (grandson of Maiturare). In 2013 Aminu Balarabe was turbaned after his father's death as Bunun Wauru (Ummaru, 1999; Ayama, 2018).

\subsubsection{Establishment of Chimmola district of old Gwadabawa district}

Chimmola Ward is among the lands belonging to Muhammadu Maiturare Gwadabawa. It was the house of Sarkin Musulmi Ahmadu Atiku. Chimmola was famous during the jihad of Usmanu Danfodiyo. It was initially the base where Sarkin Gummi situated his army when he came to augment Sarkingobir Alkalawa Yunfa, which was turned into a town by Amadu Atiku 
(by the authority of Usman Danfodiyo) and utilized as Capital during the reign of Amadu on the Caliphate throne. Chimmola is situated few kilometres from Dagel, the town of Shehu. It was haply believed to be a parcel of Dagel. Shehu Danfodiyo used to lock himself in Chimmola to serve his God in a move to shun the disturbance from some of his folks at Dagel. Therein, at Chimmola, situated the tomb of Sarkin Musulmi Amadu (Sayudi\& Boyd, 1974; Sokoto State History Bureau,1979; Jabo, 2008; Ayama, 2018). Several people led the Chimmola ward as village heads; they are echoed in the below table-7.

Table-7: Showing the leaders of Chimmola from Atikawa house since its creation

\begin{tabular}{|l|l|l|}
\hline Name of leader & $\begin{array}{l}\text { Duration of } \\
\text { reign }\end{array}$ & Comment \\
\hline Amadu Atiku & & Son of Sarkin Musulmi Atiku \\
\hline Magaji Atto & & \\
\hline Magaji Bello & & \\
\hline Muhammadu Kwasau Dangaladima & 1 year & \\
\hline Sardauna Mahe & 2 years & \\
\hline Sardauna Muhammadu Zayyanu & 16 years & Son of Sarkingobir Abdurrahman \\
\hline Sardauna Alu & 6 years & Son of Sarkingobir Abdurrahman \\
\hline Sardauna Namadina & 23 years & \\
\hline Maiakwai & 1998 -date & \\
\hline
\end{tabular}

In 2001, Sokoto state government under the leadership of Attahiru Bafarawa, Chimmola was carved out from Gwadabawa District, and Mansur Abdulrahman (grandson of Sarkin Musulmi Maiturare) was appointed as Sarkingabas Chimmola. After the death of the first Sarkingabas, the successor is Ahmad Mansur (the eldest son of Sarkingabas mansur) (Ummaru, 1999; Ayama, 2018).

\subsubsection{Creation of Asara of Gwadabawa}

Asara village was initially formed before establishing Gwadabawa town by Sarkin Musulmi Maiturare before he ascended the Sultanate stool. People who lead Asara Ward were: Muhammadu Bello Abdurrahman, Mamman Dan Asara, Sarkin Rafi Hamza, Marafa Ummaru, Marafa Ibrahimu, Ahmad, Marafa Ummaru Mansur. In 2020, Sokoto Sultanate and State Government made a new District of Asara, and Musa Sarkingobir Adiya was appointed as the substantive District Head. The only new District was singlehandedly created against Sarkingobir Gwadabawa (Sarkingobir, 2021d).

\subsubsection{Mammande ward of Gwadabawametropolitan district}

The Mammande inhabitants were originally from the Fulani clan. The region is an old one and characterized with the legendary tokens since the time of Sarkin Musulmi Amadu Zaruku. Since the creation of Mammande, many people rose to their leadership stool They include: Ardo Danbo (Wakili), Ardo Wakaso, Ardo Mamman, Ardo Ummaru, Amadu, Sarkin Rafi Mahe (son of Sarkingobir Abdurrahman Gwadabawa), Ardo Abubakar, Ardo Ummaru (Ummaru, 1999). 


\subsubsection{Huchiward of Gwadabawa district}

Huchi is part of olden day Gwadabawa District. Huchi was created by Sarkin Musulmi Atiku to his son. Huchiand Mammande are led by Sarkin Musulmi Atiku scions. It is a place versatile for farming more especially during the dry season. Leaders of HUCHI include: Dangaladima Haliru, Dangaladima Marafa, Dangaladima Isa Fari, Dangaladima Muhammadu, Dangaladima M. Dasuki, Dangaladima Muhammadu, Dangaladima Ummaru Kwasau, Dangaladima Shehu, Dangaladima Aliyu, Dangaladima Abubakar 1, Dangaladima Abubakar Ardo 2 (Ummaru, 1999; Sarkingobir, 2021a; Sarkingobir, 2021b).

\subsubsection{Other chieftaincy positions belonging to Atikawa}

Marafa- This sarauta was given to Maiturare. It represents a prince of the Caliphate and an influential figure. He was the only person to have been the Marafa of the Daular Usmaniyya during his time. As a powerful prince, he was required with the title of Marafa. He then created the Gwadabawa District from nothing. Because he was the originator of Gwadabawa, he was popularly called Marafa Gwadabawa. He dually excited his duty as owner and district Head of Gwadabawa and as prince of the Caliphate (who is an influential councilor of the Sarkin Musulmi and served in many capacities assigned to him by the Sarkin Musulmi in the Sokoto Caliphate. This is presently, the title of Ubankasar Gada, HakiminAsara and others (Sarkingobir, 2021a; Sarkingobir, 2021b).

a. Sarkingobir: This title was given to Sarkingobir Ahmadu and his successors. It served as the center of Atikawa in Sokoto. The title is connected to the conquest of Gobirawa, which the Fulani did during the jihad. Somebody who is Sarkingobir is waiting for the Sarkin Musulmi throne and has always been the leading contender. The Maiturare, and Tambari became Sarkin Musulmi after holding the title (Ummaru, 1999).

b. Bunu: Bunu is a title of District Head Tangaza, Village Head Dimbiso, District Head of Wauru, Hakimin Kalaba and relations.

c. Sarkin Rafi: Is a title at Kaddi District, Illela District, and others.

d. SarkinGabas: Is a title at Chimmola District

e. Sardaunan Sokoto: Is a title that was held by Sarkingobir Abdujatau and Abdun Mamma. Once a member of Sultanate Council and a great figure with significant responsibilities at the Sultanate such as prison, works, police, and relations.

f. Dangaladiman Sokoto: Abbas held this title, and it is the title of Sarautar Huchi. Dangaladima was also allocated to the Village head of Takatuku in Bodinga local government, Sokoto. Once upon a time, the people of Takatuku had been ravaged by insecurity and thefts, then they sought Sarkin Musulmi's help; therefore, he appointed an individual from the Atiku house to reside as leader of Takatuku to solve their complaints. Henceforth, the title was still bonafide of Atikawa.

g. Wamban Sokoto: This title is accorded to a prince who helps his relatives and works for the SarkinMusulmi. It was given to Aliyu Kyari Abdurrahman, and his successor is his son, Foduye Aliyu Kyari. 
h. Ardon: This title is given to Ardon Mammande and relations.

i. Dangaladima: This title was for Dangaladiman Huchi, the village head of Huchi, Gwadabawa local government. Other places where Atikawa are the rightful heirs to the throne include Wushishi, Fajaldu (DangeShuni), Takatuku (Bodinga), Dimbiso (Wurno), Rijira Dorowa (Sokoto Metropolis), Sabon Birnin (Sokoto Metropolis), among others.

\section{Brief account of Kontagora Emirate of Niger state, Nigeria}

Kontagora is situated in the North-western part of Niger State, Nigeria, 200 kilometres away from the state capital of Niger state. The name Kontagora was derived when the followers of Umaru Nagwamatse, the founder of Kontagora, said,"Mu kwantarda Gorarmu mu Debi Ruwa" meaning, we should slant our Gora/bucket to fetch water in one lake. The town/city of Kontagora was created by Umaru Nagwamatse (a Sokoto Prince) circa 1842-1859 after several battles with the Kambari, Dakarawa, Kamunku, Bassa, Gwari, Dukkawa, and the relations. It was established as a ribat and in the course of the jihad movement. "Make ready for them all thou canst of (armed) force and of horses tethered, that thereby ye may dismay the enemy of Allah and your enemy, and others beside them who ye know not. Allah knoweth them. Whatsoever ye spend in the way of Allah it will be repaid to you in full, and ye will not be wronged" Quran:8:60. "Those who believed and left their homes and strove for the cause of Allah, and those who took them in and helped them are the believers in truth. For them is pardon, and a bountiful provision" Quran:8:74. It is noteworthy that these regions were once visited by Shehu Abdullahi, Sarkin Musulmi Muhammadu Bello, and their troops for jihad cause. Thus, after the initial jihad, consolidation is needed as it is usual for many people to retrace or act otherwise (Ummaru, 1999).

In 1859, Ahmadu Zaruku bn Sarkin Musulmi Abubakar Atiku 1 ascended the throne as the Sarkin Musulmi. He then fully acknowledged and hymned the territory created by Umaru Nagwamatse and accorded him the title of Sarkin Sudan Kontagora, the king of the blacks. This title is prestigious, and reverence awarded to his brave brother because of his giant strides in safeguarding and emancipation of the Caliphate. The name Sudan was derived from the Arabic word meaning "black"; therefore, the whole land in Africa is regarded as black land by non-Africans. Umaru Nagwamatse passed away in 1876 after 17 years of battles to create the Kontagora and after spending 17 years on the throne as Sarkin Sudan. He died at Anaba and was buried at Mamba. Then his eldest son Abubakar Modibbo ascended the throne as $2^{\text {nd }}$ Sarkin Sudan Kontagora. Before his ascension, he was summoned from Wushishi and turbaned at Kontagora. Ibrahim Nagwamatse became the $3^{\text {rd }}$ Emir of Kontagora in 1880. Ibrahim was popularly known as one who inherited the warrior-ship of Umaru Nagwamatse. He perpetuated the battles started by his father. He continued from where his father started; that is why he is popularly called Cigari, the defeater of towns; because he used to defeat or clear towns belonging to his enemies (Ummaru, 1999).

By 1898, the Royal Niger Company had set a force towards Sokoto under the pretext of helping the Sarkin Musulmi against the French. But the real aim of the Company was to establish an advanced military post near Sokoto and to get the Caliph to accept a British Resident in his capital. When tension mounted, the Sultan sent the Emir of Kontagora (at the head of a force of 7,000 horsemen) to tell the British forces to go back or be attacked (Audu \& Osuala, 2015). In 1902, the British invaders reached his domain (Kontagora), and he fought them fiercely till he and his troops migrated. The invaders overtook them at a place called Kaya (Zaria land), 
from where he was in exile at Lokoja, where he dedicated his life to teaching Islam and its tenets (Ummaru, 1999). Later in 1903, he was returned to the throne due to some spectacular events that unfolded therein. At the time of the invasion, the area was about 27,000 square miles and with a population of about 75,500. Sarkin Sudan Ibrahim died in 1929 and was succeeded by Umaru Maidubu (the $4^{\text {th }}$ Sarkin Sudan). In 1961 Umaru Maidubu passed away and was succeeded by Muazu Ibrahim ( $5^{\text {th }}$ Sarkin Sudan). Muazu Ibrahim died in 1974 and was succeeded by Saidu Namaska (the $6^{\text {th }}$ Sarkin Sudan, who is longest serving Sarkin Sudan of Kontagora). Saidu Namaska is the son of Sarkin Kudu (Hakimin Kaboji), and he is the grandson of Sarkin Sudan Ibrahim (Ummaru, 1999).

Table-8: The ascension of Sarkin Sudan throne from Nagwamatse to Saidu Namaska

\begin{tabular}{|l|l|}
\hline Name & Year \\
\hline Mallam Umaru Nagwamatse & $1859-1876$ \\
\hline Mallam Abubakar Modibbo bn Umaru & $1876-1880$ \\
\hline Mallam Ibrahim bn Umar Nagwamatse & $1880-1929$ \\
\hline Mallam Umaru Maidubu & $1929-1961$ \\
\hline Muazu Ibrahim Nagwamatse & $1961-1974$ \\
\hline Saidu Namaska bn Umaru Namaska (Sarkin Kudu) & $1974-2021$ \\
\hline
\end{tabular}

\section{Saidu Namaska: The present Sarkin Sudan (Emir) of Kontagora}

The Alhaji Saidu Namaska attended his education from an elementary school between 19451950. Therein, he attended Bida Middle School (1950-1953). In 1957-1962 he was appointed as Mallamin Hakimi. In 1962 he attended Ahmadu Bello University (ABU) Zaria and obtained a certificate in the judiciary. Therein, he proceeded to get the Advanced Judicial Certificate, which he scored with first-class status. In 1968-1974 he was president of the Area Court. In 1974, Saidu Namaska was turbaned as Sarkin Sudan Kontagora as the $6^{\text {th }}$ on the throne (Ummaru, 1999).

Saidu Namsaka is a huge personality highly revered by all and sundry. He is highly determined with vigor and strivings in all he does. He is a well-known large-scale farmer who cultivates crops and rear animals. His agricultural zeal made him the most prominent farmer in the whole land of Kontagora. He practiced both dry and rainy farming activities. It is well-known that Kontagora land is famous for its vast agricultural land and the land of farmers. In terms of governance, Saidu Namaska always listens to his subjects day and night. He always helps his followers. He dispelled backbiting and rumourmongering. He is always straightforward and executes law and order without minding whose ox is gored (Ummaru, 1999). He died in on the month of September 2021 after a protracted illness. He spent 47 years on the throne and after his death 47 contenders vied for filling his gap.

\section{Sarkin Musulmi Attahiru-1 and Sultan of Maiyurno Sudan Republic}

The Attahiru 1 was born at Chimmola, district of Gwadabawa, Sokoto Caliphate; he was raised there to the family of Sarkin Musulmi Ahmadu Atiku bn Shehu Danfodio. Attahiru had established a village called Darnar Kango when he was a prince. Attahiru was very learned, erudite, and well-cultured. 
In 1902, Muhammadu Maiturare Marafa Gwadabawa, the brother to Attahiru, influenced the emergence of Attahiru as the $12^{\text {th }}$ Caliph of Shehu by the bid of Almighty Allah. Until his appointment, he was sitting at Chimmola, which is located about 30 kilometres away from Sokoto City. No wonder his appointment was in a move to furnish the Caliphate with a suitable successor that can stir well the affairs of the Caliphate at its most trying time when the British are hell-bent on invading it. Attahiru became Sarkin Musulmi or Caliph in 1902-1903. Circa, he spent about nine months on the throne. His period was concise but very interesting in the history of the Sokoto Caliphate because it was the time when the Independence of Sokoto Caliphate was on the verge of been threatened by British invaders. He came on the throne in a period of significant challenges and hardship. Attahiru, in the course of his reign he demonstrated courage, virility, and commitment to safeguarding the tradition of Islam and his forefathers (Abba et al., 2017).

After the fall of Sokoto City to the British forces, Attahiru migrated towards the East, but he was vigorously fought and killed by the British troops at Bormi in the now Gombe state. Before his death, he delegated his son and entourage to reach Makkah. Part of this delegation reached Makkah, part of it became dispersed to many parts of the world such as America, Mali, and relations. Sultan Attahiru's son, Muhammadu Bello Maiyurno, succeeded and established a city called Maiyurno (bearing his name) at the present-day Sudan Republic. The descendants of Attahiru are still holding the Sarkin Musulmi or Sultan of Maiyurno City in the Sudan Republic (Jabo, 2008; Abba, 2017). The scions of Attahiru that had been on Maiyurno sultanate were listed in table-9.

Table-9: The descendants of Sarkin Musulmi Attahiru on the throne of Maiyurno Sultanate

\begin{tabular}{|l|l|l|}
\hline Name & Title & Reign \\
\hline $\begin{array}{l}\text { Muhammadu Bello Maiyurno bn Sarkin } \\
\text { Musulmi Attahiru }\end{array}$ & Sarkin Musulmi & $1903-1940$ \\
\hline Muhammadu Tahir bn Maiyurno & Sultan & $1940-1969$ \\
\hline Muhammadu Bello bn Tahir & Sultan & $1969-1970$ \\
\hline Alhaji Abubakar bn Tahir & Sultan & $1970-2016$ \\
\hline Ali bn Muhammadu Tahir & Sultan & 2016- Date \\
\hline
\end{tabular}

\section{Conclusion}

Concisely, we have seen how some descendants of Sultan (Sarkin Musulmi) Abubakar Atiku 1 (including himself) rose to the Sultanate throne of Sokoto in Africa. They are Sultan Ahmad Atiku, Sultan Abdurrahman Atiku, Sultan Muhammadu Attahiru, Sultan Muhammadu Maiturare, and Sultan Tambari. The descendants of Atiku created many towns and villages and contributed to the development of the famous African Sokoto Caliphate. The domains created includes: Gwadabawa, Jabo, Chimmola, Gada, Illela, Danchadi etc. One famous warrior of the Atiku dynasty was the Umaru Nagwamatse, who formed the giant Kontagora Emirate from nothing. Umaru was recognized as the Sarkin Sudan of Kontagora by his elder brother, Sultan Ahmad Atiku for the outstanding work he did. Saidu Namaska was the longest serving descendants of Nagwamatse on Kontagora's stool. Saidu rained from 1974-2021.

Noteworthy, the independence of Sokoto Caliphate was seized during the time of Sultan Attahiru Ahmad. Attahiru fought vigorously to safeguard the Caliphate and ultimately, he lost 
his life along with many of his people. The death of Attahiru led to the spill over of Shehu's cause to many parts of the world, thereby having an international status. Thus, this paper illustrated selected scions of Sarkin Musulmi Abubakar Atiku 1 and their domains where they hold the rights as heirs to the hegemonies. They had demonstrated their own augments to guard the Sokoto Caliphate. They are many, and their domains are many. There is a need for further studies to reveal the history of the Sokoto Caliphate to the public to increase awareness.

\section{Acknowledgment}

We are grateful to the following personalities for their immense contribution to the development of this paper: His Royal Highness Muhammadu Bello Ayama (District Head of Gongono, Tangaza Local Government), Ummaru Jekada Ummaru (Danmasanin Gwadabawa), Prof. Sambo Wali Junaid (Wazirin Sokoto), HRH Muhammadu Namadina Abdurrahman (Talban Sokoto), Sheikh Usman Garba Jabo, Engineer Nasiru S. Fada and all authors that we used their literature works.

\section{Declaration of conflict of interest}

The author(s) declared no potential conflicts of interest(s) with respect to the research, authorship, and/or publication of this article.

\section{Funding}

The author(s) received no financial support for the research, authorship and/or publication of this article.

\section{References}

Abba, A., Jumare, I. M., \& Aliyu, S. S. (2017). Sultans of Sokoto: A biographical history since 1804. Arewa House Center for Historical Documentation and Research, Ahmadu Bello University, Zaria. https://www.worldcat.org/title/sultans-of-sokoto-abiographical-history-since-1804/oclc/993295033

Audu, M. S., \& Osuala, U. S. (2015). The British Conquest and Resistance of Sokoto Caliphate, 1897-1903: Crisis, Conflicts, and Resistance. Historical Research Letter, 22, 29-43. https://www.iiste.org/Journals/index.php/HRL/article/view/23886

Ayama, B. M. (2018). Takaitaccentarihin Masarautar Gwadabawa. Kalenjeni Printing Press Sokoto.

Jabo, U. S. B. (2008). Takaitaccentarihin Sarkin Gobir: Alhaji Muhammadu Zayyanu (MFR) da Masarautar Gwadabawa.

Johnston, I. (2010). Harmattan, A Wind of Change: Life and Letters from Northern Nigeria at the end of Empire. The Radcliffe

Press.https://www.sahistory.org.za/sites/default/files/archivefiles/carolyn_johnston_harmattan_a_wind_of_change_libook4you.pdf

Johsnton, H. A. S. (1967). The Fulani Empire of Sokoto. Oxford University.

Ministry of Information, Cultural, and Internal affairs, Sokoto State (1979). Introducing Sokoto State. Obadaki Press Limited. 
Sarkingobir, Y \& Sharu, A. U. (2021). Citation on the $14^{\text {th }}$ Sultan of Sokoto: Sultan Muhammadu Maiturare. Electronic Research Journal of Social Sciences and Humanities, 3(2), 16-24. $\quad$ http://www.eresearchjournal.com/wpcontent/uploads/2021/06/3.-MS-of-SOKOTO.pdf

Sarkingobir, Y. (2020a). The brief history of the 7th Sarkingobir of Gwadabawa, Alhaji Muhammadu Zayyanu MFR. International Journal of Educational Research and Studies, 2(1), 01-06. http://www.journalofeducation.net/archives/2020.v2.i1.29

Sarkingobir, Y.(2020b). The second Sarki Rafi IllelaAlh Buhari Muhammad Tukur. Usmanu Dafodiyo Univesity, Sokoto.

Sarkingobir, Y. (2021a). A brief account on Gwadabawa Semiemirate/metropolitan district: Yesterday and today. Frontiers of Knowledge Journal Series: International Journal $\begin{array}{llll}\text { of Social } & \text { Sciences, } & \text { 16-24. }\end{array}$ http://www.smrpi.com/images/journals/0903574530.pdf

Sarkingobir, Y. (2021b). The brief History of Sultan Muhammadu Maiturare of Sokoto Caliphate and Sarkingobir Abdurrahman Gwadabawa. Lambert Academic Publishing. https://www.lap-publishing.com/catalog/details//store/gb/book/978-6204-18171-4/the-brief-history-of-sultan-muhammadu-maiturare-of-sokoto-caliphate

Sayudi, S. \& Boyd, J. (1974). Infakul Maisuri Na sarkin Musulmi Muhammadu Bello. Northern Nigerian Publishing Company Limited.

Shareef, M. (2005). Zaman' n-Nasaara' The Hour of the Christians' African Muslim Resistance to European Colonialism. Sankore Institute of Islamic - African Studies International.www.sankore.org/www.siiasi.org

Sheriff, V. F., \& Altine, Z. (2018). The struggle of Shaykh Uthman bn Foduye in reformation of faith and social vices among the people of Gobir Kingdom: a critical analysis. Saudi Journal of Humanities and Social Sciences, 3(7), 886-891. http://scholarsmepub.com/wp-content/uploads/2018/08/SJHSS-37-886-891-c.pdf

Sokoto State History Bureau (1979). Abdu Jatau District Head Gwadabawa, Skt/97/4/45.

Tibenderana, P.K. (1997). The making and unmaking of Sultan of Sokoto Muhammadu Tambari; 1922-1931. Journal of the Historical Society of Nigeria,9(1), 93134.https://www.jstor.org/stable/41857054

Ummaru, U.J. (1999). Daular Atikawa. An unpublished document prepared by Danmasanin Gwadabawa Ummaru Jekada Ummaru. 